\title{
Studi Literatur Gambaran Hasil Pemeriksaan Procalcitonin Sebagai Biomarker Pada Pasien Sepsis
}

\author{
* Cahyawati Rahayu' ${ }^{1)}$, Melati Yuliantina Anjani' ${ }^{1)}$ \\ ${ }^{1}$ Prodi Analis Kesehatan, Fakultas Kesehatan, Universitas Mohammad Husni Thamrin, Jakarta \\ *Correspodence author: Cahyawati Rahayu, rahayucahyawati@gmail.com, Jakarta, Indonesia
}

\begin{abstract}
Abstrak
Sepsis adalah penyakit sistemik yang disebabkan karena adanya mikroba atau toksin ke dalam aliran darah dan menimbulkan respon sistemik. Sepsis masih menjadi penyebab kematian utama pada kasus kritis di berbagai penjuru dunia dan masih menjadi masalah di negara berkembang maupun di negara maju. Belakangan ini dikenal suatu pemeriksaan Procalcitonin (PCT) yang digunakan sebagai penanda spesifik bakterial berat dan dapat membedakan antara sepsis dengan SIRS (Systemic Inflammatory Response Syndrome). Penelitian dengan judul Studi Literatur Gambaran Hasil Pemeriksaan Procalcitonin Sebagai Biomarker Pada Pasien Sepsis bertujuan untuk mengetahui gambaran hasil Procalcitonin pada pasien sepsis berdasarkan usia, jenis kelamin, komorbiditas dan faktor-faktor yang berhubungan dengan hasil pemeriksaan Procalcitonin.

Jenis penelitian yang digunakan adalah telaah dari jurnal 2010-2020 yang terkait dengan judul. Kemudian hasil yang didapat oleh para peneliti dari seluruh jurnal dibahas untuk mengetahui gambaran hasil procalcitonin pada pasien sepsis dan faktor-faktor yang berhubungan dengan hasil pemeriksaan procalcitonin.

Hasil penelitian menunjukkan bahwa usia 40-70 tahun dan jenis kelamin laki-laki adalah yang paling banyak mengalami sepsis dengan sumber sepsis terbanyak disebabkan oleh penyakit saluran pernafasan seperti pneumonia diikuti dengan penyakit hipertensi dan diabetes melitus. Kesimpulan dari hasil telaah adalah insiden penderita sepsis masih tinggi. Usia dan penyakit yang mendasari sepsis memiliki hubungan dengan hasil pemeriksaan procalcitonin.
\end{abstract}

Kata Kunci : Sepsis, Procalcitonin, Biomarker

\begin{abstract}
Sepsis is a systemic disease caused by the presence of microbes or poisons into the bloodstream and causes a systemic response. Sepsis is still a leading cause of death in critical cases in various parts of the world and is still a problem in developing countries and in developed countries. It has been recently discovered that Procalcitonin (PCT) testing is used as a marker of specific bacteria and can distinguish between sepsis and SIRS (Systemic Inflammatory Response Syndrome). The study titled Procalcitonin Examination Results as a Biomarker in Patient Sepsis aims to determine the description of Procalcitonin results in sepsis patients based on age, sex, comorbidity and factors related to Procalcitonin examination results.

This type of research is a literature review from the journal 2010-2020 related to the title. Then the results obtained by researchers from all journals were discussed to determine procalcitonin results in sepsis patients and factors related to procalcitonin examination results.

The study showed that age 40-70 years and male sex were the most experienced by sepsis with the most sources of sepsis caused by respiratory diseases such as pneumonia followed by hypertension and diabetes melitus. The conclusion from the review is that the incidence of sepsis is still high. Age and underlying disease of sepsis have a relationship with procalcitonin results.
\end{abstract}

Keywords $\quad$ :Sepsis, Procalcitonin, Biomarker

Open Journal System (OJS): journal.thamrin.ac.id 


\section{PENDAHULUAN}

Sepsis merupakan suatu respon inflamasi sistemik terhadap infeksi, dimana patogen atau toksin dilepaskan ke dalam sirkulasi darah sehingga terjadi aktivasi proses inflamasi (PERDACI, 2014).

Pada tahun 2010 WHO (World Health Organization) menerbitkan bahwa sepsis adalah penyebab kematian utama di ruang perawatan intensif pada negara maju dan insidensinya mengalami kenaikan. Insiden sepsis di dunia diperkirakan 1,8 juta kasus/tahun, 25-38\% diantaranya membutuhkan perawatan di ICU dan mortalitas 1.400 kasus/hari (Gaieski et al, 2013; Dellinger et al, 2012; Rhee et al, 2014; Irwan, 2012). Menurut Centers for Disease Control and Prevention/CDC (2020) di Amerika ada lebih dari 1,5 juta kasus sepsis setiap tahunnya. Jenis infeksi ini membunuh lebih dari 250.000 orang Amerika per tahunnya. Kondisi serupa juga terjadi di negara Mongolia, dimana penyakit infeksi merupakan 10 penyebab kematian tertinggi di negara tersebut (Bataar O et al, 2010).

Data yang akurat tentang sepsis belum didapatkan di Indonesia. Insiden sepsis di beberapa Rumah Sakit rujukan berkisar 15-37,2\%, sedangkan mortalitas 37-80\%. Di RS Dr. Ciptomangukusumo Jakarta dilaporkan insiden sepsis 25\% dengan angka mortalitas 77,3\%. Kemudian di RS Dr. Sardjito Yogyakarta, jumlah kasus sepsis menunjukkan variasi dari tahun ke tahun, rata-rata jumlah kasus 3 tahun terakhir kurang lebih 275 pertahun (25,8\%) dan angka mortalitas 72,9\% (Irwan, 2012; Rajab, 2012). Di Indonesia prevalensi kejadian sepsis pada pasien rawat inap Rumah Sakit dr. Sutomo Surabaya sebesar 58,33\%, penderita sepsis berat sebesar 27,08\% dan pasien dengan syok sepsis sebanyak 14,58\% (Tambajong et al, 2015).

Sepsis dapat menjadi parah pada pasien dengan komorbiditas seperti Diabetes Melitus (DM) dan pneumonia. Berdasarkan data Riskesdas (2018), period prevalensi penyakit infeksi saluran pernafasan akut berdasarkan diagnosis sebesar 4,4\%. Namun, untuk period prevalensi pneumonia berdasarkan diagnosis di Indonesia sebesar 2,0\% khususnya DKI Jakarta sebesar $>2,0 \%$ (Riskesdas, 2018). Tempat infeksi yang paling sering menjadi sumber utama sepsis adalah paru (55\%), saluran kemih (22\%), perut $(6,6 \%)$ dan infeksi kulit atau jaringan lunak $(5,5 \%)$ (Sieswerda et al, 2020). 
Tes laboratorium alternatif untuk menegakkan infeksi bakterial seperti Laju Endap Darah (LED), C-Reactive Protein (CRP), dan jumlah leukosit tidak memiliki sensitifitas dan spesifisitas yang diinginkan (Kibe et al, 2011).

Procalcitonin (PCT) merupakan penanda spesifik bakterial berat dan dapat membedakan antara sepsis dengan SIRS (Systemic Inflamatory Response Syndrome) (Pangalila, 2014). Procalcitonin (PCT) lebih sensitif yang memiliki sensitivitas $85 \%$ dan spesifisitas $91 \%$ serta kadarnya paling cepat naik setelah terjadi paparan infeksi bakterial dibanding biomarker sepsis lainnya (Balci et al., 2010).

Pengukuran Procalcitonin sebagai biomarker sepsis adalah yang paling memenuhi syarat tetapi biaya pemeriksaan PCT yang relatif mahal membuat beberapa pelayanan kesehatan tidak menyediakan pemeriksaan PCT, sehingga banyak yang masih menggunakan tes laboratorium seperti jumlah leukosit ataupun hitung jenis leukosit untuk mengetahui adanya proses-proses inflamasi (Wacker et al, 2013).

Berdasarkan latar belakang diatas maka peneliti tertarik untuk melakukan penelitian yang berjudul Studi Literatur Gambaran Hasil Pemeriksaan Procalcitonin Sebagai Biomarker Pada Pasien Sepsis dikarenakan insiden sepsis di dunia terutama Indonesia masih tinggi.

\section{METODOLOGI PENELITIAN}

Review literatur dimulai dari awal penyusunan proposal sampai dengan akhir penyusunan laporan pada bulan Februari sampai dengan Juli 2020 dan ditulis di Universitas MH Thamrin. Karya Tulis Ilmiah (KTI) ini dibuat berdasarkan exploration of literature review Gambaran Hasil Pemeriksaan Procalcitonin Pada Pasien Sepsis.

Proses pengumpulan data dilakukan dengan penyaringan berdasarkan kriteria yang ditentukan dari setiap jurnal yang di ambil. adapun kriteria pengumpulan jurnal sebagai berikut: Tahun sumber literatur yang diambil mulai tahun 2010 sampai dengan 2020, kesesuaian keyword penulisan, keterkaitan hasil penulisan dan pembahasan. Studi literatur bisa didapat dari jurnal dan buku dengan batas tahun yang telah ditentukan. Strategi dalam pengumpulan jurnal berbagai literatur dengan menggunakan situs jurnal yang sudah terakreditasi seperti WHO, Riskesdas, PubMed, NCBI, Schoolar, NEJM, dan seterusnya. Melakukan pencarian berdasarkan judul penelitian secara lengkap agar didapatkan hasil jurnal yang relevan. Setelah 
mendapatkan dan mengumpulkan data-data dari sumber jurnal penelitian yang terkait, lakukan pembahasan dari hasil tersebut. Sebelum peneliti membuat kesimpulan dari data-data yang terdapat dalam literatur, peneliti akan mengidentifikasi dalam bentuk ringkasan secara singkat berupa tabel yang berisi nama peneliti dan hasil yang diteliti. Setelah melakukan pembahasan telaah literatur maka buatlah kesimpulan.

Metode penelitian yang dilakukan oleh literatur-literatur yang peneliti dapatkan yaitu menggunakan cross sectional dan deskriptif. Pengambilan sampel menggunakan consecutive sampling, yaitu dengan cara pengambilan sampel yang dilakukan dengan cara memilih sampel yang memenuhi kriteria penelitian sampai kurun waktu tertentu sehingga jumlah sampel terpenuhi. Analisis data menggunakan analisis univariat dan analisis bivariat.

Penelitian ini merupakan studi penelitian menggunakan teknik telaah literatur penelitian yang terkait dengan judul. Penelitian Telaah Literatur merupakah ikhtisar komprehensif tentang penelitian yang sudah dilakukan mengenai topik yang spesifik untuk menunjukkan kepada pembaca apa yang sudah diketahui tentang topik tersebut dan apa yang belum diketahui, untuk mencari rasional dari penelitian yang sudah dilakukan atau untuk ide penelitian selanjutnya (Denney \& Tewksbury, 2013).

Telaah literatur bisa didapat dari berbagai sumber baik jurnal, buku, maupun pustaka. Metode Telaah Literatur adalah serangkaian kegiatan yang berkenaan dengn metode pengumpulan data pustaka, membaca dan mencatat, serta mengelola bahan penulisan (Nursalam, 2016).

\section{HASIL DAN PEMBAHASAN Hasil}

Berdasarkan review terhadap jurnal yang mengulas tentang pemeriksaan procalcitonin dengan judul studi literatur gambaran hasil pemeriksaan procalcitonin sebagai biomarker pada pasien sepsis didapatkan data sebagai berikut.

Tabel 1

Distribusi Frekuensi Penderita Sepsis Terbanyak Berdasarkan Jenis Kelamin Pada 10 Jurnal.

\begin{tabular}{ccc}
\hline Jenis Kelamin & $\mathbf{f}$ & \% \\
\hline Laki-laki & 6 & 60 \\
\hline Perempuan & 3 & 30 \\
\hline Tidak dibedakan & 1 & 10 \\
\hline
\end{tabular}


Berdasarkan Tabel 1, distribusi berdasarkan jenis kelamin pada penderita sepsis terhadap 10 jurnal didapatkan hasil penderita sepsis terbanyak pada jenis kelamin laki-laki sebanyak 6 jurnal (60\%) yaitu pada jurnal Intansari et al (2014), Octavia S (2015), Schuetz et al (2017), Salawaty EN (2019), Kharyadi E (2019), dan Nurdani (2019). Kemudian pada perempuan 3 jurnal (30\%) yaitu Frisca P (2012), Tambajong R (2015), dan Suwondo (2015). Sedangkan hasil jumlah tidak berbeda pada penderita sepsis sebanyak 1 jurnal (10\%) yaitu pada jurnal Jekarl (2019).

Pada tabel dibawah ini adalah hasil review 6 dari 10 jurnal dikarenakan 4 jurnal lainnya tidak mencantumkan data usia penderita sepsis pada penelitiannya.

Tabel 2

Distribusi Penderita Sepsis Pada 6 Jurnal Berdasarkan Usia.

\begin{tabular}{ccc}
\hline No & Penulis & Usia (tahun) \\
\hline $\mathbf{1}$ & Frisca P (2012) & $61-70$ \\
\hline $\mathbf{2}$ & Octavia S (2015) & $40-59$ \\
\hline $\mathbf{3}$ & Tambajong R (2016) & $45-59$ \\
\hline $\mathbf{4}$ & Kharyadi E (2019) & $55-64$ \\
\hline $\mathbf{5}$ & Nurdani et al (2019) & $48-58$ \\
\hline $\mathbf{6}$ & Salawaty EN (2019) & $51-60$ \\
\hline
\end{tabular}

Berdasarkan Tabel 2, distribusi berdasarkan usia pada penderita sepsis terhadap 6 jurnal didapatkan usia pada jurnal Frisca P (2012) 61-70 tahun, Octavia S (2015) 40-59 tahun, Tambajong R (2016) 45-59 tahun, Kharyadi E (2019) 55-64 tahun, Nurdani et al (2019) 48-58 tahun, dan Salawaty EN (2019) 51-60 tahun.

Pada tabel hasil pemeriksaan Procalcitonin dibawah ini hanya menelaah 5 dari 10 jurnal dikarenakan 5 jurnal lainnya tidak mencantumkan data hasil pemeriksaan pada penderita sepsis sehingga tidak dapat diolah.

Tabel 3

Hasil Pemeriksaan Procalcitonin Pada Penderita Sepsis Berdasarkan 5 Jurnal.

\begin{tabular}{cccc}
\hline No & Penulis & \multicolumn{2}{c}{ Nilai Normal (n) } \\
\cline { 3 - 4 } & & Normal & Abnormal \\
\hline $\mathbf{1}$ & Frisca P (2012) & 12 & 15 \\
\hline $\mathbf{2}$ & Octavia S (2015) & 33 & 10 \\
\hline $\mathbf{3}$ & Schuetz et al (2017) & 264 & 382 \\
\hline $\mathbf{4}$ & Kharyadi E (2019) & 40 & 90 \\
\hline $\mathbf{5}$ & Salawaty EN (2019) & 28 & 57 \\
\hline
\end{tabular}


Berdasarkan tabel 3, hasil pemeriksaan Procalcitonin terhadap pasien sepsis menunjukkan bahwa yang memiliki hasil terbanyak pada kategori abnormal ada 4 jurnal (80\%) yaitu Frisca $\mathrm{P}$ (2012), Schuetz et al (2017), Kharyadi E (2019), dan Salawaty EN (2019). Sedangkan yang memiliki hasil terbanyak pada kategori normal ada 1 jurnal (20\%) yaitu pada Octavia S (2015).

Pada tabel 6, hanya menelaah 5 dari 10 jurnal dikarenakan 5 jurnal lainnya tidak mencantumkan penyakit utama pada penderita sepsis.

Tabel 4

Gambaran Hasil Procalcitonin Pada Penderita Sepsis Berdasarkan Penyakit Utama Dari 5 Jurnal.

\begin{tabular}{ccc}
\hline & n jurnal & $\%$ \\
\hline $\begin{array}{c}\text { Saluran } \\
\text { Pernafasan }\end{array}$ & 2 & 40 \\
\hline Jaringan Lunak & 2 & 40 \\
\hline Post Operasi & 1 & 20 \\
\hline
\end{tabular}

Berdasarkan penyakit utama pada penderita sepsis pada tabel 6 menunjukkan bahwa penyakit pada saluran pernafasan dan jaringan lunak menjadi penyakit utama paling banyak pada penderita sepsi diikuti post operasi.

Pada tabel 4, hanya menelaah 5 dari 10 jurnal dikarenakan 5 jurnal lainnya tidak mencantumkan penyakit penyerta.komorbiditas pada penderita sepsis.

\section{Tabel 5}

Gambaran Hasil Procalcitonin Pada Penderita Sepsis Berdasarkan Penyakit Penyerta dari 5 Jurnal.

\begin{tabular}{ccc}
\hline & n jurnal & $\%$ \\
\hline Pneumonia & 3 & 50 \\
\hline Hipertensi & 2 & 33,3 \\
\hline Diabetes Melitus & 1 & 16,7 \\
\hline
\end{tabular}

Berdasarkan penyakit penyerta (komorbiditas) pada tabel 7 menunjukkan bahwa penyakit pneumonia menjadi penyakit penyerta paling banyak pada pasien sepsis diikuti penyakit hipertensi dan diabetes melitus.

Pada tabel 5, hanya menelaah 3 dari 10 jurnal dikarenakan 7 jurnal lainnya tidak mencantumkan usia-usia yang memiki kadar $>10,0 \mathrm{ng} / \mathrm{ml}$ atau memiliki kadar PCT yang sangat meningkat. 
Tabel 6

Gambaran Hasil Procalcitonin Pada Penderita Sepsis

Berdasarkan Usia.

\begin{tabular}{ccc}
\hline No & Penulis & Usia (tahun) \\
\hline $\mathbf{1}$ & Schuetz et al (2017) & $56-84$ \\
\hline $\mathbf{2}$ & Kharyadi E (2019) & $48-65$ \\
\hline $\mathbf{3}$ & Salawaty EN (2019) & $38-75$ \\
\hline
\end{tabular}

Berdasarkan tabel 6 didapatkan usia yang mempengaruhi hasil dari pemeriksaan Procalcitonin berkisar antara 38-84 tahun.

\section{PEMBAHASAN}

Faktor penyebab sepsis didominasi oleh infeksi bakteri dan diperlukan identifikasi dini berupa biomarker. Parameter procalcitonin (PCT) menjadi parameter baku emas (procalcitonin $>2 \mathrm{ng} / \mathrm{ml} \rightarrow$ infeksi bakteri) untuk memprediksi infeksi bakteri pada pasien sepsis. Keterbatasan dan kekurangan parameter procalcitonin dalam memprediksi infeksi bakteri terutama pada faktor biaya dan ketidaktersediaan di fasilitas kesehatan (Silalahi, 2015). Pada kondisi inflamasi sistemik yang erat, sepsis berat dan disfungsi organ, PCT dapat digunakan sebagai parameter untuk memperkirakan keparahan, membantu menentukan tindakan selanjutnya untuk hasil yang lebih baik, dan menurunkan mortalitas (Dharaniyadewi, 2015).

Metode untuk pemeriksaan PCT seperti immunofluorescent assay pada alat BRAHMS KRYPTOR, ELFA (Enzyme-Linked Fluorescent Assay) pada alat VIDAS BRAHMS PCT, dan metode immunokromatografi pada Rapid Test PCT.

Hasil review dari 10 jurnal berdasarkan jenis kelamin pada penderita sepsis didapatkan hasil pada laki-laki lebih besar sebanyak 6 jurnal (60\%) dibandingkan dengan perempuan yakni pada jurnal Intansari et al (2014), Octavia S (2015), Schuetz et al (2017), Salawaty EN (2019), Kharyadi E (2019), dan Nurdani et al (2019). Sedangkan pada jurnal Frisca P (2012), Tambajong R (2015), dan Suwondo (2015) pada perempuan 3 jurnal (30\%) dan pada jurnal Jekarl et al (2019) hasil sama atau tidak dibedakan (10\%). Hasil tinggi pada laki-laki didukung literatur yang mengatakan bahwa hormon testosteron laki-laki cenderung merendam respons kekebalan tubuh dan hormon estrogen perempuan dapat meningkatkan jumlah sel imun. Selain itu laki-laki cenderung mengalami infeksi pada organ paru-paru yang dikarenakan faktor resiko 
seperti perilaku merokok, sedangkan perempuan cenderung mengalami infeksi saluran kemih. Perempuan memiliki 10\% kemungkinan terkena sepsis dan meninggal dunia (Traci M, 2013).

Hasil review dari 10 jurnal berdasarkan kelompok usia pada penderita sepsis didapatkan hasil terbanyak pada usia 40-70 tahun. Hal ini disebabkan seiring dengan bertambahnya usia maka sistem imun juga semakin menurun sehingga infeksi atau keaadan sepsis dapat lebih mudah terjadi. Adanya respon imun bawaan dan respon imun adaptif menurun oleh penuaan yang sebagian besar memberi kontribusi terhadap peningkatan kejadian infeksi pada orang tua. Beberapa perubahan yang berkaitan dengan usia sel-sel dari sistem kekebalan tubuh bawaaan yang juga merupakan faktor penyebab sistem imun menurun. Dalam sistem imun adaptif, jumlah sel B dan generasi sel T menurun oleh penuaan yang menyebabkan berkurangnya sistem tanggapan terhadap patogen baru, namun kemampuan untuk melakukan respon yang efisien untuk patogen tetap utuh. Di samping itu tipe infeksi dan kecenderungan penyakit infeksi yang menyebabkan sepsis juga dipengaruhi oleh usia.

Hasil review dari 5 jurnal berdasarkan nilai Procalcitonin (PCT) didapatkan hasil PCT yang melebihi nilai normal sebanyak 4 jurnal (80\%) yaitu pada jurnal Frisca P (2012), Schuetz et al (2017), Salawaty EN (2019), dan Kharyadi E (2019). Sedangkan, hasil PCT yang kurang dari nilai normal terdapat pada 1 jurnal (20\%) yaitu pada jurnal Octavia S (2015). Pada keadaan fisiologis kadar PCT rendah bahkan tidak terdapati, tetapi meningkat bila terjadi bakterimia atau fungimia yang timbul sesuai dengan berat infeksi. PCT diinduksi oleh endotoksin yang dihasilkan bakteri selama infeksi sistemik. Kadar PCT muncul cepat dalam 2 jam setelah rangsangan, puncaknya 12 sampai 48 jam dan secara perlahan menurun dalam 48 sampai 72 jam. Pada jurnal Octavia S (2015) menyatakan bahwa ketidaksesuaian disebabkan karena faktor komorbiditas dan kesalahan saat melakukan pemeriksaan laboratorium pada waktu kadar PCT dalam darah belum meningkat. Hal ini sesuai dengan penelitian Ismy J (2011) dan Dharaniyadewi (2015) yang mengatakan bahwa konsentrasi PCT yang rendah akan memperlihatkan hasil yang palsu atau negatif palsu, jika dilakukan pemeriksaan yang terlalu dini yaitu pada awal perjalanan infeksi setelah timbulnya sakit.

Hasil review dari 5 jurnal berdasarkan penyakit utama yang dimiliki penderita sepsis didapatkan bahwa penyakit pada saluran pernafasan dan jaringan lunak menjadi penyakit utama dari penderita sepsis diikuti post operasi. Berdasarkan kepustakaan, infeksi pada saluran 
pernafasan dapat memicu terjadinya sepsis. Sepsis yang timbul akibat infeksi bakteri, virus, atau jamur pada paru-paru tersebut.

Hasil review dari 5 jurnal berdasarkan komorbiditas pada penderita sepsis didapatkan hasil lebih banyak pada penyakit saluran pernafasan seperti pneumonia sebanyak 3 jurnal (50\%) diikuti hipertensi 2 jurnal (33,3\%), dan diabetes melitus 1 jurnal (16,7\%). Berdasarkan kepustakaan mendiagnosa pasien sepsis harus mempertimbangkan kemungkinan lokasi infeksi. Ada 3 lokasi yang biasanya infeksi pada sepsis, yaitu: paru-paru, saluran kencing dan luka bekas operasi. Pasien dengan komorbiditas terutama pasien di ICU memiliki resiko meninggal bukanya hanya dari penyakit kritis yang diderita tetapi juga ada faktor kedua yaitu penyakit nosokomial seperti infeksi. Pneumonia adalah penyakit nosokomial infeksi paling umum kedua di ICU. Berdasarkan data dan kepustakaan yang ada, sepsis yang penyakit dasarnya adalah pneumonia paling banyak disebabkan karena penggunaan Ventilator-Associated Pneumonia (VAP) sehingga dapat mendasari diagnosa sepsis pneumonia.

Hasil review dari beberapa jurnal didapatkan faktor yang berhubungan dengan hasil pemeriksaan procalcitonin pada penderita sepsis ialah faktor usia dengan kisaran usia 38-84 tahun dan komorbiditas. Menurut Tambajong (2016) angka kejadian sepsis dipengaruhi usia dan jenis penyakit yang mendasarinya. Hal ini sama seperti yang dikatakan Traci M (2013) bahwa sepsis tergantung pada umur dan lokasi infeksi atau penyakit dasar.

Kekurangan dari penelitian ini yaitu sulit mendapatkan data yang lengkap antara satu jurnal dengan yang lainnya membuat hasil yang didapat kurang relevan.

\section{SIMPULAN DAN SARAN}

Setelah dilakukan penelitian studi literatur tentang studi literatur gambaran hasil pemeriksaan procalcitonin sebagai biomarker pada penderita sepsis berdasarkan 10 jurnal yang di review, peneliti dapat mengambil kesimpulan sebagai berikut : Jenis kelamin penderita sepsis banyak dialami oleh penderita berjenis kelamin laki-laki sebanyak 6 jurnal (60\%), perempuan 3 jurnal (30\%), dan tidak dibedakan 1 jurnal (10\%). Usia penderita sepsis didominasi pasien usia 40-70 tahun. Kadar procalcitonin penderita sepsis dengan kategori melebihi nilai normal sebanyak 4 jurnal. Faktor usia dan komorbiditas (pneumonia, hipertensi, dan diabetes melitus) menjadi faktor yang mempengaruhi hasil tes procalcitonin. 


\section{REFERENSI}

Boudma, L., Luyt, C.E., Tubach, F., et al. (2010). Use of Procalcitonin to Reduce Patients Exposure to Antibiotics in Intensive Care Units: A Multicentre Randomised Controlled Trial. Lancet. 375 , 436-474.

Bataar, O., Dünser, MW., Tsenddorj, G., Lundeg, G., Jochberger, S., Jakob ,S. (2010). Helfen Berührt Study Team Intensive care medicine in Mongolia's 3 largest cities: outlining the needs. J Crit Care.

Cawcutt, KA., Peter, SG. (2014). Severe sepsis and septic shock: Clinical overview and update on management. Mayo Clinic Proceedings Journal. Vol 89 (11), 1572-1578.

Centers for Disease Control and Prevention (CDC). Sepsis. (2020). [Internet] Cited 2020 May 15. Available on https://www.cdc.gov/

Dellinger, RP., Levy, MM., Rhodes, A., Annane, D., Gerlach, H., Opal, SM., Sevransky, JE., et al. (2013). Surviving Sepsis Campaign: International Guidelines for Management of Severe Sepsis and Septic Shock, 2012. Crit Care Med J. 39:165-228.

Dharaniyadewi, D., Lie KC., Suwarto, S. (2015). Peran Procalcitonin Sebagai Penanda Inflamasi Sistemik Pada Sepsis. Jurnal Penyakit Dalam Indonesia. Vol.2, No.2.

Elisabet, M. (2018). Korelasi Antara Neutrophil-Lymphocyte Ratio Dengan Kadar Procalsitonin Pada Pasien Sepsis. [Skripsi]. Surakarta : Universitas Setia Budi Surakarta.

Frisca, Putu. (2012). Faktor yang berhubungan dengan hasil tes prokalsitonin pada sepsis - Studi kasus di RSUP dr. Kariadi Semarang. [Skripsi] Semarang : Universitas Diponegoro Semarang.

Gaieski et al. (2013). Benchmarking the incidence and mortality of severe sepsis in the United States. Critical Care Medicine 41(5), 1167-1174.

Gilbert, David N. (2010). Minireview use of plasma procalcitonin levels as an adjunct to clinical microbiology. Jurnal of clinical microbiology. 48(7) : 2325-2329.

Herman, Rahman, Hari Asti. (2019). Prokalsitonin dan kultur darah sebagai penanda sepsis di RSUD DR. Wahidin Sudirohusodo Makassar. Vol.10 No.2.

Intansari, US., Dartini, N., Kismardhani. (2014). Peramalan Sepsis Akibat Procalcitonin Terkait Keluaran Hasil Klinis. Indonesian Journal of Clinical Pathology and Medical Laboratory. Vol 20 No.2.

Irwan, D., Hamidah, Purwati, Triyono, Bramanto, Afianto V, et al. (2012). Profil penderita sepsis akibat bakteri penghasil ESBL. Jurnal Penyakit Dalam. 13(1):63-8.

Jekarl, DW., Lee, S., Kim, M., Kim, Y., Woo, SH., Lee, WJ. (2019). Procalcitonin as a prognostic marker for sepsis based on SEPSIS-3. Journal of Clinical Laboratory Analysis.

Ismy, J. (2011). Biomarker Sepsis pada Pasien Panyakit Kritis. Banda Aceh: Fakultas Kedokteran Universitas Syiah Kuala.

Keputusan Menteri Kesehatan Republik Indonesia (KMK RI). (2017). Pedoman nasional pelayanan kedokteran tata laksana sepsis. Nomor HK.01.07/MENKES/342/2017.

Khair, K.B., Rahman, M.A., Sultana, T. (2010). Role of Hematologic Scoring System in Early Diagnosis of Neonatal Septicemia. BSMMU Journal. 3, 62-67.

Kharyadi, E. (2019). Hubungan procalsitonin (PCT) dengan jumlah leukosit pada pasien sepsis di Rumah Sakit Umum Daerah (RSUD) Budhi Asih Jakarta Timur. [KTI]. Jakarta: Universitas MH.Thamrin.

Kibe S, Adams K, Barlow G. (2011). Diagnostic and prognostic biomarkers of sepsis in critical care. J Antimicrob Chemother.

Lagu, Tara et al. (2012). Hospitalizations, costs, and outcome of severe sepsis in the United States 2003 to 2007. Crit Care Med.

Mayer FB, Yende S, Angus DC. (2013). Epidemiology of severe sepsis virulence. 5(1):411.Meissner, M. 2010. Procalcitonin-Biochemistry and Clinical Diagnosis. UNIMED Verlag AG, D-28323 Bremen.

Open Journal System (OJS): journal.thamrin.ac.id 
Octavia, S. (2015). Hubungan antara Leukosit dengan Prokalsitonin sebagai Biomarker Sepsis di Rumah Sakit Umum Pusat Haji Adam Malik Bulan Agustus - Oktober 2015. [Skripsi]. Medan: Fakultas Kedokteran Universitas Sumatera Utara.

Pangalila, F. (2014). Procalsitonin Benefit in the Treatment of Sepsis. Makalah dalam The 6th Continuing Professional Development on Clinical Pathology and Laboratory Expo 2014. Yogyakarta.

PERDACI (Perhimpunan Dokter Intensive Care Indonesia). (2014). Penatalaksanaan Sepsis dan Syok Septik : Surviving Sepsis Campaign Bundle, September.

Rajab, R. (2014). Hubungan kadar laktat dengan disfungsi organ multipel pada pasien sepsis di Makassar [Tesis]. Makassar: Universitas Hasanuddin.

Rhee, C., Gohil, S., Klompas, M. (2014). Regulatory mandates for sepsis care-reasons for caution. N Engl J Med. 370(18):1673-76.

Rijal, I. (2011). Perbedaan nilai parameter Bioelectrical Impedance Analysis (BIA) pada pasien pria sepsis HIV dan non HIV. [Tesis]. Medan: Universitas Sumateran Utara.

Riset Kesehatan Dasar (RISKESDAS). (2018). Badan penelitian dan pengembangan kesehatan Kementrian RI tahun 2018. Diakses: 31 Mei 2020 dari www.depkes.go.id.

Sandesc, Dorel. (2003). Sepsis: A Review (I). Timisoara medical journal. [internet] Cited 2020 May 15. Available on http://www.tmj.or/

Sieswerda, E et al. (2020). The Dutch Working Party on Antibiotic Policy (SWAB) guideline for empirical antibacterial therapy of sepsis in adults. Amsterdam. Stichting Werkgroep Antibioticabeleid.

Schuetz, P., Birkhahn, R., Sherwin, R., et al. (2017). Serial Procalcitonin predicts mortality in severe sepsis patients: results from the multicenter procalcitonin monitoring sepsis (MOSES) study. Crit Care Med.45:781-789.

Soreng, Katherine, Ph.D., Levy, Roma, M.S. (2011). Procalcitonin: an Emerging Biomarker of Bacterial Sepsis. Los Angeles. Clinical Microbiology Newsletter [Internet]. Vol 33: 171-178.

Salawaty, EN. (2019). Gambaran hasil pemeriksaan procalcitonin pada pasien sepsis di RSPAD Gatot Soebroto 2018. [KTI]. Jakarta : Poltekkes Kemenkes Jakarta III.

Singer M, Deutschman CS, Seymour CS, Annane D, Hari MS, Bauer M. et al. (2016) The third international consensus definitions for sepsis and septic shock. JAMA. 315(8):801-10

Stearns-Kurosawa, DJ., Osuchowski, MF., Valentine, C., Kurosawa, S., Remick, DG. (2011) The Pathogenesis of Sepsis. Boston, Massachusetts. Annu, Rev. Pathol. Mech. Dis. 6:19-48.

Suhaymi, E., Fikri, E., Nasution, I. (2016). Perbandingan Akurasi Diagnostik Kadar Procalcitonin dan C-Reactive Protein pada Pasien Appendisitis Anak di RSUP Haji Adam Malik Medan dan RSUD Dr. Pirngardi Medan.

Suhendro. (2017). Definisi dan kriteria terbaru diagnosis sepsis: Sepsis-3. In: Widayat D, Leonard N. Jakarta antimicrobial update "Antimicrobial Usage in Clinical Practice L Strategy to Combat Infectious Agent 2017”. Jakarta: Interna Publishing. P, 1-7.

Suryanto, CA. (2012). Uji diagnostik prokalsitonin dibandingkan dengan kultur darah sebagai baku emas diagnosis sepsis bakterial di RSUP dr. Kariadi. Semarang : Universitas Diponegoro Semarang.

Tambajong RN, Lalenoh DC, Kumaat L. (2016). Profil penderita sepsis di ICU RSUP Prof. Dr. R.D. Kandou Manado periode Desember 2014 - $\quad$ November 2015. Jurnal e-Clinic (eCl). 4(1):452-7.

Wacker, C., Prkno, A., Brunkhorst, F. And Schlattmann, P. (2013). Procalcitonin as a diagnostic marker for sepsis: a systematic review and meta-analysis. The Lancet Infectiouns Disease.

World Health Organization (WHO). Sepsis. (2010). [Internet] Cited 2020 May 15]. Available on https://www.who.int/

Open Journal System (OJS): journal.thamrin.ac.id 